\title{
PALATAL RUGAE AND LIP PRINT PATTERN STUDY AS THE ALTERNATIVE METHOD OF MASS NATURE DISASTER VICTIM IDENTIFICATION
}

\author{
Nila Kasuma ${ }^{1 *}$, Fildzah Nurul Fajrin ${ }^{2}$, Dewi Elianora ${ }^{3}$, Aida Fitriana ${ }^{1}$ and Haria Fitri ${ }^{1}$ \\ ${ }^{I}$ Andalas University, Faculty of Dentistry, Indonesia \\ ${ }^{2}$ Andalas University, Faculty of Medicine, Indonesia \\ ${ }^{3}$ Baiturahmah University, Faculty of Dentistry, Indonesia
}

\begin{abstract}
The most common method of forensic identification is dental, fingerprint, and DNA. However those have a limitation such as high price , and limited cases. Palatal fold (rugae) and lip print pattern are a unique, stable and resistant morphological landmark foridentification. The purpose of this study is to examine the characteristic of rugae palatina and lip print pattern and the resemblance to the Minangkabau family relationship. This cross-sectional study, in 27 pure blood Minangkabaunese families. The sample was taken randomly. Palatal rugae was extracted from alginate printing. Lip print was taken on white paper after lips colored with red lipstick. IBM SPSS 17 is used for statistical analysis. The results show that there is similarity of rugae palatina based on family relationship. The circular male rugae has similarities to that of the father ( $p<0.05)$. Circular rugae in girls is derived from the mother, wavy ones are derived from both parents $(p<0.05)$.. Lip print pattern doesn't show the significant result. Conclusion is similarities of rugae palatina are influenced by genetic factors. Rugae palatina is good alternative identification method in forensic science. Palatal rugae pattern can be considered to be taken in routine dental medical record.
\end{abstract}

Keywords: palatal rugae, lip print pattern, odontology forensic

\section{Introduction}

Introduction

After the tsunami in the northern island of Sumatra, Indonesia in 2004, earthquakes occurred periodically moving southward to the Sunda Strait. The Province of West Sumatra is located in the western part of Sumatra island which has become an international focus because of frequent disasters and the discovery of seismic gaps that could potentially cause an earthquake of magnitude 8.8 - 8.9 SL (Imamura et al., 2012). The most common ethnic groups in West Sumatra are Minangkabau ethnic. Minangkabau has the only matrilineal lineage in Indonesia (Fanany, 2014). A total of 7 districts and cities are disaster prone areas with 921,349 people living in the red zone (Imamura et al., 2012).

Identification of disaster victims is a very challenging process in forensic science. At this time the most commonly used methods are fingerprint, dental and DNA identification. DNA is the most accurate but very expensive, especially in large natural disasters.Dental identification is very useful in natural disasters that cause very many casualties, even success reaches 75\%(Rath and Reginald, 2014). However there are certain case when these methods cannot be done, therefore the secondary method need to be conducted .

Rugae palatina is a unique and potential oral cavity landmark if a dental method cannot establish identification (Sharma, Saxena and Rathod, 2009). "Rugae Palatina" is terminology which refers to a series of irregular elevated ridges produced by folding of palatal mucose membrane on hard palate anterior part, spreading from papilla incisivum transversely.In 1932, Trobo Hermosa, a Spanish investigator proposed the study of palatal rugae is called "Palatoscopy" or "Rugoscopy"(Pillai et al., 2016) . 
For the first time, in 1932 Edmond Locard proposed an identification method using lip print pattern. This method is called cheiloscopy (Narwal et al., 2014). Lip print pattern is the cracks (sulci labiorum) in the form of wrinkle and groove on the lips transition zone between labial mucosa and skin (vermilion border) (Khanna, 2015). Because of the accuracy, simplicity, efficiency, lip print pattern is considered as the alternative secondary forensic identification method. Lip print pattern is usually collected by various ways. Cottone (1981) introduced using lipstick as the easiest way to trace the pattern (Sandhu et al., 2012).

The uniqueness of the structure of the rugae palatina and lip print patterns can be questioned whether it can determine the similarity between relatives in one family. The purpose of this study is to examine the similarity of palatal and lip print pattern among family members in native Minangkabau ethnic groups

\section{Method}

This cross sectional study included 27 families consist of father, mother, and biological daughter and son which is chosen randomly in 3 native Minangkabau district : Luhak 50 Kota, Luhak Agam , and Luhak Tanah Datar. This study have qualified the ethical clearance on September 2017 (ethical clearance No. 080/KEP/FK 2017). Respondent signed informed consent after being informed about the purpose and instructions of this study . Data were collected from October 2017 - February 2018 .

Maxillary impression was made with irreversible hydrocolloid impression material (alginate) (CGC scent) on impression tray. Dental cast was made with mixture of dental stone type 3 and water which is mixed based on $\mathrm{W}: \mathrm{P}$ ratio . The cast was analyzed twice by 2 observers,. Palatal rugae on the cast were measured and classified according to shape with Thomas - Kotze method and size with Sunita Kapali method.

Thomas- Khotze

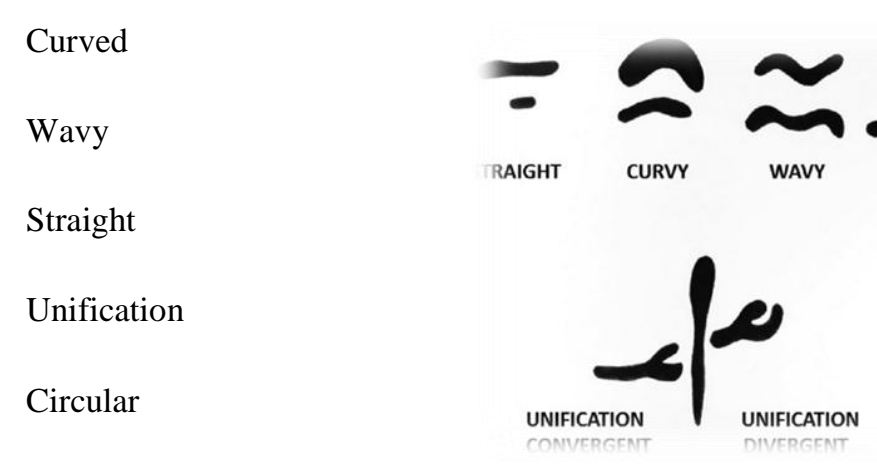

Sunita Kapali

Primary $\begin{aligned} & \text { A }-5 \text { to } 10 \mathrm{~mm} \\ & \text { B }-10 \mathrm{~mm} \text { or more }\end{aligned}$

Secondary

Secondary rugae $(3-5 \mathrm{~mm})$

Fragmentary $\quad$ Fragmentary Rugae $(<3 \mathrm{~mm})$ 
Lip print pattern were collected with lipstick method. The respondents were asked to put a red lipstick (CPixy) on their lips and let it drier for 1 minute. Lip prints were taking on a $10 \mathrm{~cm}$ length cellophane tape with respondents open their lips slightly and press evenly from central to lateral part of lips for seconds. The tape was removed then attached in a piece of white paper. The paper was scanned by scanner then analyzed and classified according to Suzuki-Tsuchihashi lip print pattern classification as follows : (Tsuchihashi, 1974)

Table 1. Lip print pattern classification by Suzuki-Tsuchihashi (Tsuchihashi, 1974)

\begin{tabular}{cc}
\hline Type I & $\begin{array}{c}\text { Clear-cut grooves running vertically across the lip } \\
\text { Type I' }\end{array} \begin{array}{r}\text { The grooves are straight but disappear half-way instead of } \\
\text { covering the entire breadth of the lip }\end{array}$ \\
\hline Type II & The grooves fork in their course \\
\hline Type III & The grooves intersect \\
\hline Type IV & The grooves are reticulate \\
\hline Type V & The grooves do not fall into any of the Types I-IV, and cannot be \\
differentiated morphologically
\end{tabular}

Data were analysed using IBM SPSS 15 statistical software. Goodness of fit test was used to examine the similarities between pattern among family members .

\section{Result}

This study took place in 3 native Minangkabau districts (Luhan Nan Tigo). Guguak, Situjuh and Tanjung represented Luhak 50 Kota. Luhak Tanah Datar was represented with Tanjung Baru and Baso, Banuhampu and Tanjung Raya in Luhak Agam . Twenty seven families were observed, but only 13 families had complete family consist of father, mother and son, and 11 families had father, mother and daughter.

Table 2. Similarities of palatal rugae pattern

\section{P-VAlue}

\begin{tabular}{|c|c|c|c|c|c|c|c|c|c|}
\hline & & \multicolumn{5}{|c|}{ Rugae shape } & \multicolumn{3}{|c|}{ Rugae size } \\
\hline & & Curve & Straight & Wavy & Unification & Circular & Primary & Secondary & Fragmented \\
\hline \multirow{4}{*}{$\begin{array}{c}\text { Son } \\
n=13\end{array}$} & $\beta_{0}$ & 134 & ,021 & ,075 & 121 & 602 & ,005 & 132 & 130 \\
\hline & $\beta_{1}$ & ,694 & ,573 & 104 & ,596 & ,006 & ,515 & ,323 & ,332 \\
\hline & $\beta_{2}$ & ,321 & 299 & ,483 & ,935 & 375 & 189 & 174 & 473 \\
\hline & $\begin{array}{c}\text { model } \\
y\end{array}$ & ,599 & ,498 & 215 & 871 & ,019 & 319 & 188 & ,682 \\
\hline \multirow{4}{*}{$\begin{array}{c}\text { Daughter } \\
n=10\end{array}$} & $\beta_{0}$ & ,246 & 204 & ,031 & 177 & 349 & ,007 & ,086 & ,456 \\
\hline & $\beta_{1}$ & ,452 & ,302 & ,097 & ,367 & ,011 & ,264 & ,534 & ,991 \\
\hline & $\beta_{2}$ & 796 & 132 & ,029 & ,735 & ,020 & ,762 & ,286 & ,099 \\
\hline & $\begin{array}{c}\text { model } \\
y\end{array}$ & ,763 & 147 & ,091 & ,611 & ,037 & ,478 & 235 & ,343 \\
\hline
\end{tabular}

The shape and size of rugae do not show a significant similarity relationship between children - father and child - mother. But there are specific patterns that can be derived. Circular rugae on boys tends to be inherited from father $(p=0,011)$. Circular rugae pattern on girls is derived from father and mother, wavy rugae come from the mothers $(\mathrm{p}<0.05)$. Meanwhile in lip print analysis, the pattern doesn't show the significant similarity between children and parents . 
Table 3. Similarities of lip print pattern

\begin{tabular}{|c|c|c|c|c|c|c|}
\hline \multirow[b]{2}{*}{ Quadrant } & & \multicolumn{4}{|c|}{ Goodness of fit } & \multirow{2}{*}{ p-value } \\
\hline & & I & II & III & IV & \\
\hline \multirow[t]{4}{*}{$\begin{array}{c}\text { Son } \\
n=13\end{array}$} & $\beta_{0}$ &, 526 & ,879 & ,289 & ,084 & ,270 \\
\hline & $\beta_{1}$ & ,322 &, 051 & ,235 & ,728 & ,881 \\
\hline & $\beta_{2}$ & 659 & ,195 &, 160 & ,446 & , 106 \\
\hline & $\mathrm{Y}$ & ,589 & ,066 & ,243 & ,629 & ,247 \\
\hline \multirow[t]{4}{*}{$\begin{array}{c}\text { Daughter } \\
n=13\end{array}$} & $\beta_{0}$ & ,697 & ,093 & ,436 & ,566 & ,839 \\
\hline & $\beta_{1}$ & ,477 & ,955 & ,305 & ,790 & 083 \\
\hline & $\beta_{2}$ & ,076 & ,355 & ,498 & ,939 & ,946 \\
\hline & $\mathrm{Y}$ &, 111 &, 618 & ,500 & ,962 & 200 \\
\hline
\end{tabular}

\section{Discussion}

Serving legal matters and community services are another tasks for dentist aside doing examination, diagnosis, and treatment of oral and maxillofacial lesions. Forensic identification is one of humanity service dentists can do to help victim investigation and legal affairs .

Postmortem reports, Finger prints, DNA and dental record are known to be successful primary method to identify victims in forensic science field. If the primary method is not sufficient, secondary method is needed. Lip print and palatal rugae pattern can be instrument in forensic identification and verification of a person presence on the crime scene (Sharma, Saxena and Rathod, 2009)

This current study was carried out to find out whether there is any association between parents and children lip print patterns. The result of our study is there's no significant similar lip print pattern inherited from parents to children means there are no patterns which is very identical. The pattern was completely different from parent, and this difference is considered to be individualistic and unique. Our result is in concordance with Silpha et al study who find no significant association among family members(Shilpa Patel, IshPaul, Madhusudan.A.S., Gayathri Ramesh, 2010). This study use lipstick to record the pattern. This method is have weakness because the oil and moisture secretion from sebaceous and sweat gland on the edges of the lips can change the prints. Also the smudging of lip prints because of uneven pressure on the lips while taking the records leading to unidentified pattern.(Sharma, Saxena and Rathod, 2009). While recording the pattern, observer should pay more attention when pressing the tape to avoid smudging. Therefore further study should be carried out with larger sample size and latest imaging technologies.

From this study it can be concluded that the shape of rugae can be used to determine the relationship and similarity between relatives. On boys, the most shape derived from his father is circular pattern. This is similar to our previous pilot project (Kasuma et al., 2014) states that the rugae circular pattern is similar between children and parents. This result is in concordance with Pasiga and Hardianti's (Daeng Pasiga and Hardianti, 2017) who did study on Bugise ethnic. The form of rugae is more similar between father and child than mother and child. In girls, the circular pattern is inherited from father and mother, while the wavy pattern come from mother. This result has similarities with the study (Patel et al., 2015) which states the relationship of the rugae pattern shows a positive correlation between the child and his parents. Wavy rugae patterns are derived more from the mother than from the father.

The shape of the rugae palatina pattern is derived by the parents. Genetics affects the formation of morphologic characteristics so that the pattern is not the same for everyone. According to Mendel's theory, each parent's gene 
will be passed to his child. The inherited properties will be seen if the gene is the dominant gene. Environmental factors influence the formation of palatine rugae, and are determined by genes. Genes regulate the orientation of collagen fibers during embryogenesis and the diversity of palatine rugae patterns in different populations. Palatine rugae is formed in the 3rd intrauterine month, its growth is regulated by epithelial-mesenchymal interactions in which extracellular matrix molecules are expressed during this development(Kasuma et al., 2014).

Palatal rugae shape is stable and the quality and quantity doesn't change due to aging. This characteristics is caused by the rugae position in oral cavity. Palatal rugae is protected by tongue, teeth, cheecks, and alveolar process, ensure it to be not impaired by trauma, orthodontics treatment and finger sucking (Pillai et al., 2016). Palatal rugae is unique topography, no one have similar pattern. Because of the uniqueness and accuracy that match fingerprints identification, palatal rugae pattern is taken as medical record document in South America, especially in certain case where fingerprints cannot be collected(Paliwal, Wanjari and Parwani, 2010; Wichnieski et al., 2012). Another specialty of palatal rugae is the durability .Palatal rugae can last up to 7 days after death and can withstand heat, for example degree 3 burn. Because of its uniqueness, stability, and resistance to damage it is this that causes rugae palatina to be a very potential anatomical landmark (Pillai et al., 2016).

\section{Conclusion}

There is a hereditary factor in the pattern of palatal rugae. Lip print pattern doesn't show the significant similarities among family members but the pattern is different from each other's. Palatal rugae can be a genetic marker for identification in the future. We hope this research can contribute to the forensic odontology especially in the Minang and Deutro Malays

\section{Acknowledgement}

This research was supported supported and funded by Ministry of Research, Technology and Higher Education Republic Indonesia. We thank our colleagues from Andalas University who provided insight and expertise that greatly assisted the research.

\section{Reference}

Daeng Pasiga, B. and Hardianti, L. S. (2017) 'Palatal Rugae Pattern Based on Lineage (Pilot study for ethnic bugise - South of Sulawesi Indonesia)', International Journal of Research, 04(13), pp. 1310-1315.

Fanany, R. (2014) 'The Experience of Old Age in West Sumatra, Indonesia: Culture Shift and Cultural Consonance in the Modern Era', The International Journal of Aging and Society www . agingandsociety . com, 3, pp. 2160-1909.

Imamura, F. et al. (2012) 'Tsunami disaster mitigation by integrating comprehensive countermeasures in Padang city, Indonesia', Journal of Disaster Research. doi: 10.20965/jdr.2012.p0048.

Kasuma, N. et al. (2014) 'Palatal Rugae Pattern Identification to Determine Family Lineage in Minangkabau, West Sumatera, Indonesia', Indian Journal of Forensic Medicine \& Toxicology, 12(April-June 2018), pp. 1-7.

Khanna, S. (2015) 'Cheiloscopy: A Frequency Based Approach for IV Quadrant in Female Lip Print', Journal of Forensic Research. OMICS International, 06(03), pp. 1-8. doi: 10.4172/2157-7145.1000280.

Narwal, A. et al. (2014) 'Cheiloscopy - An Adjunct in Identification of Familial Lineage', 8(May), pp. 82-86.

Paliwal, A., Wanjari, S. and Parwani, R. (2010) 'Palatal rugoscopy: Establishing identity', Journal of Forensic Dental Sciences, p. 27. doi: 10.4103/0974-2948.71054.

Patel, R. N. et al. (2015) 'Assessing the inheritance of palatal rugae patterns', 3(6), pp. 297-301.

Pillai, J. et al. (2016) 'Quantitative and qualitative analysis of palatal rugae patterns in Gujarati population: A retrospective, cross-sectional study.', Journal of forensic dental sciences, 8(3), pp. 126-134. doi: 10.4103/09751475.195110 . 
Rath, R. and Reginald, Ba. (2014) 'Palatal rugae: An effective marker in population differentiation', Journal of Forensic Dental Sciences, p. 46. doi: 10.4103/0975-1475.127771.

Sandhu, S. et al. (2012) 'Study of lip print pattern in a Punjabi population', Journal of Forensic Dental Sciences, 4(1), p. 24. doi: 10.4103/0975-1475.99157.

Sharma, P., Saxena, S. and Rathod, V. (2009) 'Cheiloscopy: The study of lip prints in sex identification', Journal of Forensic Dental Sciences, 1(1), p. 24. doi: 10.4103/0974-2948.50884.

Shilpa Patel, IshPaul, Madhusudan.A.S., Gayathri Ramesh, S. G. . (2010) 'A study of lip prints in relation to gender, family and blood group’, International Journal of Oral \& Maxillofacial Pathology, 1(1), pp. 4-7.

Tsuchihashi, Y. (1974) 'Studies on personal identification by means of lip prints', Forensic Science, 3(C), pp. 233-248. doi: 10.1016/0300-9432(74)90034-X.

Wichnieski, C. et al. (2012) 'Comparative analysis between dactyloscopy and rugoscopys', Journal of Morphological Sciences. 